\title{
Development of Cytomegalovirus and Adenovirus-Specific Memory CD4 T-Cell Functions From Birth to Adulthood
}

\author{
BÉATRICE PÉDRON, VALÉRIE GUÉRIN, DEBORA JORGE CORDEIRO, SONIA MASMOUDI, JEAN-HUGUES DALLE, \\ AND GHISLAINE STERKERS
}

\author{
Laboratory of Immunology [B.P., V.G., D.J.C., S.M., G.S.], Department of Hematology [J.-H.D.], Robert Debré Hospital, \\ Paris 75019, France
}

\begin{abstract}
Age-related changes in memory CD4 ${ }^{+}$T cells (CD4) are poorly known. To address this issue, CD4 proliferative and cytokine responses to an anti-CD3 monoclonal (CD3), to cytomegalovirus (CMV), and to adenovirus (AdV) were assessed in 57 children (age, 0.07-17.16 y) and 17 adults. Results showed i) accumulation of memory CD4 with aging, with 2-3 times more centralmemory T cell (TCM; CD45RA ${ }^{-} / \mathrm{CD} 2 \mathrm{~L}^{+}$) than effector-memory $\mathrm{T}$ cell (TEM; CD45RA ${ }^{-} / 62 \mathrm{~L}^{-}$) $\mathrm{CD} 4$ at any age. ii) In children older than $2 \mathrm{y}, \mathrm{CMV}$-specific CD4-secreting IFN $\gamma$ alone predominated over CD4-secreting IL2 + IFN $\gamma$ and a continuous increase, with aging, in IFN $\gamma$ responses to the virus was observed. In contrast, in AdV infection, CD4-secreting IL2 + IFN $\gamma$ predominated and IFN $\gamma$ responses to the virus reached adult levels from $3 \mathrm{y}$ of age. iii) In children aged $0-2 \mathrm{y}$, lower total IFN $\gamma$ responses to CMV $(p<0.02)$, $\operatorname{AdV}(p=0.05)$, and CD3 $(p<0.01)$ and lower IFN $\gamma+$ IL2responses ( $p=0.1, p<0.02, p<0.05$, respectively) contrasted with no decrease in $\mathrm{CD} 4$-secreting IFN $\gamma$ alone. Defective proliferative responses to $\mathrm{AdV}(p=0.03)$ were also observed. In conclusion, the development of memory CD4 differed in acute AdV and persistent CMV infections. Young age seemed to depress mostly polyfunctional (IL2 + IFN $\gamma$ secreting) CD4 in both infections. (Pediatr Res 69: 106-111, 2011)
\end{abstract}

$\mathrm{T}^{\mathrm{s}}$ The insight into different subsets of memory $\mathrm{T}$ cells has increased during the past few years (1). Naïve $T$ cells $\left(\mathrm{CD}^{2} 5 \mathrm{RA}^{+} / \mathrm{CD} 2 \mathrm{~L}^{+}\right)$can be distinguished from memory $\mathrm{T}$ cells $\left(\mathrm{CD}^{2} 5 \mathrm{RA}^{-}\right)$, which in turn can be further subdivided according to their capacity to enter secondary lymphoid organs. Central-memory T cells (TCM) express lymph node homing receptors (e.g. CD62L), whereas effector-memory $\mathrm{T}$ cells (TEM) do not. Each of these memory populations comprises distinct functions. TCM are thought to produce mainly IL2, whereas TEM are characterized by rapid expression of effector functions including production of IFN $\gamma$. The last subset, reexpressing CD45RA, is named terminally differentiated effector-memory CD45RA ${ }^{+} \mathrm{T}$ cell (TEMRA) cells. The function of TEMRA is less known.

The observation of a decreased proportion of memory $\mathrm{T}$ cells in young age has suggested that the naivety of the immune system likely contributes to infectious risk and poor responses to vaccination. This assumption was reinforced by

Received May 18, 2010; accepted September 21, 2010.

Correspondence: Ghislaine Sterkers, M.D., Ph.D., Laboratoire d'Immunologie, Hôpital Robert Debré, 48, Boulevard Sérurier, Paris 75019, France; e-mail: ghislaine. sterkers@rdb.aphp.fr

Supported by Assistance Publique Hôpitaux de Paris. the observation of impaired IFN $\gamma$ T-cell responses associated with increased infectious risk to intracellular pathogens in early age (2-7).

Most studies that analyzed memory CD4 T cells (CD4) to polyclonal activators or specific antigens (Ags) in early childhood focused on IFN $\gamma$ responses. As far as we know, no study has analyzed memory $\mathrm{CD} 4{ }^{+}$from birth to adulthood according to the recent knowledge that IFN $\gamma$-secreting CD4 can be further subdivided into CD4-secreting IFN $\gamma$ alone and CD4secreting IL2 + IFN $\gamma$.

The few studies that analyzed the ontogeny of memory development toward specific pathogens in early age mostly explored persistent infections by the cytomegalovirus (CMV; $8,9)$ and by HIV (2) because of their severity following mother transmission. $\mathrm{CD}^{+}$immunity toward acute infections such as rotavirus (10), Respiratory-Syncytial (11), Varicella-Zoster (12), or Influenza virus (13) have more occasionally been investigated, and cellular immunity to adenovirus (AdV) has only been analyzed in transplanted children who could not reflect physiological conditions. Finally, no study has analyzed comparatively memory T-cell development with aging in an acute and a persistent infection.

Here, we analyzed accumulation with aging of $\mathrm{CD}^{+}{ }^{+}$with TCM or TEM phenotype and also the nature and intensity levels of memory functions. The anti-CD3 MAb was used as polyclonal activator and CMV and AdV as Ags.

These two viruses were selected because virtually all children encounter $\operatorname{AdV}(14,15)$ and $\sim 50 \%$ encounter CMV during childhood in our region (this article). CMV is a prevalent $\beta$-herpes virus that establishes lifelong infections after encountering the virus at birth or during childhood or adulthood. Primary infection with CMV is usually asymptomatic in immunocompetent individuals (16). However, CMV results in prolonged viral shedding into the urine and saliva for up to several years in neonates and infants. AdV is a nonenveloped lytic DNA virus that commonly causes acute respiratory, gastrointestinal, and urinary tract diseases in children (17).

CD4 have a significant role in pathogen resistance. They provide help to B-cells and to HLA-class I-restricted T-cell

Abbreviations: AdV, adenovirus; Ag, antigen; CD4, CD4 T cells; CMV, cytomegalovirus; SI, stimulation index; TCM, central-memory T cell; TEM, effector-memory T cell; TEMRA, terminally differentiated effector-memory $\mathrm{CD}_{45 \mathrm{RA}^{+}} \mathrm{T}$ cell 
responses (18). They also play a critical role in maintaining effective cytotoxic T-lymphocyte responses $(19,20)$. Therefore, this study was designed to focus on the CD4 subset.

\section{MATERIALS AND METHODS}

Populations. Seventeen healthy adults (blood volunteer donors or hematopoietic stem cell donors) and 57 healthy children (intrafamilial hematopoietic stem cell donors) were involved in this study, which was approved by the local committee for the protection of human subjects (CPP-Ile de France VI-Groupe Hospitalier Pitié Salpêtrière). Written informed consent was provided by the parents or guardians of all children. Children were arbitrarily divided into four groups according to their age: $0-2$ y $(n=15), 3-5$ y $(n=$ $16), 6-10$ y $(n=15)$, and $11-18$ y $(n=11)$. None of the individuals evaluated immunologically evidenced clinical sign of infection at sampling.

Serology. IgG antibody titers to CMV were determined by a microtiter complement fixation test (reference Ag: Behring Lab) with titers $<1 / 8$ considered negative in all hematopoietic stem cell donors older than $1 \mathrm{y}$. AdV serology requiring additional blood sample without benefit for the donors or recipients was not feasible for ethical reasons.

Lymphocyte subset analysis. Reagents and computer software used for data acquisition and analysis were supplied by Becton-Dickinson (Facscalibur, Le Pont De Claix, France) or Beckman-Coulter (FC500, Villepinte, France). Direct immunofluorescence staining was performed on whole blood using a combination of CD4-PeCy5/CD45RA-PE/CD62L-FITC or CD3ECD/CD4-PC7/CD62L-FITC/CD45RA-PE directly labeled MAb purchased from Beckman-Coulter. In brief, $100 \mu \mathrm{L}$ of whole blood were added to a premixed solution of MAb at an appropriate dilution. Red blood cells were lysed by using FACS-lysing solution (Becton Dickinson) or Immunoprep (Beckman-Coulter). The analysis was performed using the software CellQuestPro (FACScalibur) or CXP (FC500) after gating on lymphocytes according to FSC/SSC characteristics and then to high-density CD4 expression.

Enumeration of CMV or AdV-specific cytokine-secreting cells. Peripheral blood mononuclear cells (PBMCs) were isolated by density-gradient separation $(d=1.077)$ with UNI-SEPmaxi ${ }^{+}$tubes (Novamed; AbCys, Paris, France) and resuspended at a cell density of $10^{6} / \mathrm{mL}$ in Roswell Park Memorial Institute 1640 supplemented with 10\% heat-inactivated fetal-calf serum (GIBCO, Paisley, Scotland). The culture medium also contained 10 IU/mL of recombinant IL-2 (IL2; Roche diagnostics, Meylan, France) to increase the sensibility of the assay $(21,22)$. CD28 MAb $(2 \mu \mathrm{g} / \mathrm{mL}$; Beckman Coulter Company, Marseille, France) and $2 \mu \mathrm{g} / \mathrm{mL}$ of CD $49 \mathrm{~d}$ MAb (BD biosciences, Le Pont de Claix, France) were also added. The secretion inhibitor Brefeldin A was incorporated $1 \mathrm{~h}$ after at $10 \mu \mathrm{g} / \mathrm{mL}$ (Sigma Chemical Co.). Unstimulated cells were used as negative controls. Stimulation by $0.2 \mu \mathrm{g} / \mathrm{mL}$ of CD3 MAb (Janssen-Cillag, Neuss, Germany) was used for polyclonal activation, and IL2 and CD49d MAb were omitted in CD3stimulated cultures. Titrated amounts of CMV lysate (AbCys) or AdV (Virion, Zürich, Switzerland) Ags were used for virus-specific stimulations. The AdV Ag is a consensus commercialized preparation of inactivated AdV lysate including serotypes $3,4,6$, and 7 . Based on the well-known reactivity of T cells to epitopes shared by most serotypes, this preparation is supposed to detect cellular immunity to virtually all serotypes (23). Cultures were incubated at $37^{\circ} \mathrm{C}$ in a humidified $5 \% \mathrm{CO}_{2}$ atmosphere for $18 \mathrm{~h}$. After fixation and permeabilization (IntraStain Kit; DakoCytomation, Glostrups, Denmark), cells were incubated for $20 \mathrm{~min}$ at room temperature with CD3-FITC, CD4-PerCP, IFN $\gamma$-PE, and IL2-APC MAb (BD Biosciences).

After washing, cells were analyzed on a FACSCalibur instrument using CellQuestPro software. Files were gated on small $\mathrm{CD}^{+}$lymphocytes. A minimum of 100,000 gated events were acquired. The percentage of specific cells secreting IFN $\gamma$ or IL2 was calculated as the percentage of cells secreting cytokines in stimulated cultures minus the percentage in unstimulated cultures.

Determination of T-cell proliferation. T-cell proliferation assays were performed as previously described (24). In brief, PBMCs were plated at $10^{5}$ per well, each time in triplicate. Unstimulated cells were used as negative controls. For polyclonal activation, cells were stimulated by coated a CD3 MAb (CD3; Janssen-Cillag). For virus-specific stimulation, titrated amounts of CMV (AbCys) or AdV Ag (Virion) were used at optimal concentration. Samples stimulated with CD3 were cultured for $3 \mathrm{~d}$, and samples stimulated with CMV or AdV were cultured for $6 \mathrm{~d}$ after which $\left[{ }^{3} \mathrm{H}\right]$-Thymidine $(0.8$ $\mu \mathrm{Ci} / \mathrm{mL}$; GE Healthcare) was added for $18 \mathrm{~h}$. Results are given as cpm and stimulation index (SI). SI is defined as cpm after stimulation divided by $\mathrm{cpm}$ of the negative control. A SI $>5$ associated with $\mathrm{cpm}>5000$ was considered to be a positive response.
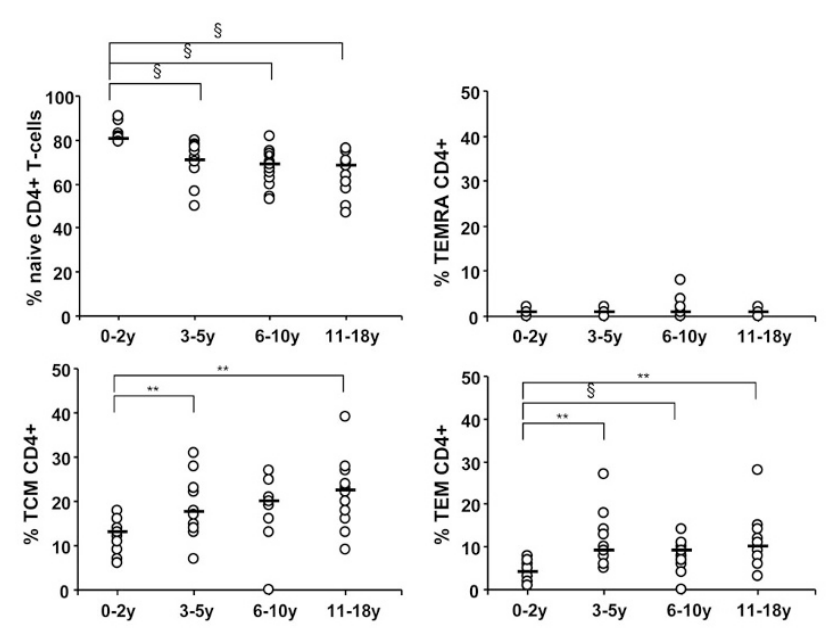

Figure 1. Percentages of lymphocyte subsets in immunocompetent children according to age group. With protein tyrosine phosphatase isoform CD45RA and $\mathrm{L}_{-}$selectin CD62L monoclonals, T cells were divided into $\mathrm{CD}_{45 \mathrm{RA}^{+} /}$ $\mathrm{CD} 2 \mathrm{~L}^{+}$(naïve), CD45RA ${ }^{-} / \mathrm{CD} 62 \mathrm{~L}^{+}$(TCM), CD45RA ${ }^{-} / \mathrm{CD}^{-} \mathrm{L}^{-}$(TEM), and $\mathrm{CD} 45 \mathrm{RA}^{+} / \mathrm{CD} 6 \mathrm{~L}^{-}$(TEMRA) cells. Results are expressed as individual percentages among total $\mathrm{CD} 4^{+} \mathrm{T}$ cells in children arbitrary divided into four groups according their age. Median values are indicated by horizontal line. Differences between groups, when significant are also indicated $(* * p \leq 0.005$; $\S p \leq 0.0005)$.

Statistical analysis. Significant differences between the different age groups of children were determined by the use of the nonparametric MannWhitney $U$ test for quantitative variable. A $p \leq 0.05$ was considered as significant.

\section{RESULTS}

Dynamic changes in the proportion of $\mathrm{CD}^{+} \mathrm{T}$ cells expressing diverse membrane memory phenotypes during childhood. The distribution of CD4 within the naif, the TCM, the TEM, and the TEMRA pools is shown in Figure 1.

As shown, memory CD4 increased with time as evidenced by decreased percentages of naïve $\mathrm{CD} 4\left(\mathrm{CD} 45 \mathrm{RA}^{+} / \mathrm{CD} 2 \mathrm{~L}^{+}\right)$ and increased levels of memory CD4 $\left(\mathrm{CD} 45 \mathrm{RA}^{-}\right)$. The conversion to the CD45RA ${ }^{-}$phenotype, that occurred mostly during the first $3 \mathrm{y}$, concerned primarily the TCM pool whatever the age. Indeed, a ratio of 3.3, 2.2, 2.4, and 2.4 TCM per 1 TEM CD4 was observed in the age groups of $0-2,3-5$, 6-10, and 11-18 y, respectively. Finally, TEMRA cells were at low levels at any age.

Dynamic changes in the IFN $\gamma$ - and proliferative responses during childhood. In agreement with a previous study (24), a high correlation between CMV-specific IFN $\gamma$-secreting CD4 $>0.03 \%$ and $\mathrm{CMV}^{+}$serologic status was found in children older than $2 \mathrm{y}$. Indeed, 20 of 21 children older than $2 \mathrm{y}$ and with a $\mathrm{CMV}^{+}$serostatus evidenced IFN $\gamma$ responses to $\mathrm{CMV}$ $>0.03 \%$, whereas none with a $\mathrm{CMV}^{-}$serostatus. Therefore, the value of $0.03 \%$ was selected as threshold of positivity in IFN $\gamma$ secretion assays.

Results on the development of total IFN $\gamma$ responses and of proliferative responses are shown in Figure 2. Low levels of IFN $\gamma$ responses to $\mathrm{CD} 3$ were observed in the $0-2$ y age group. Later, the intensity levels of IFN $\gamma$ responses increased continuously with aging. In contrast, variations with aging in the level of proliferative responses to CD3 were not obvious. 

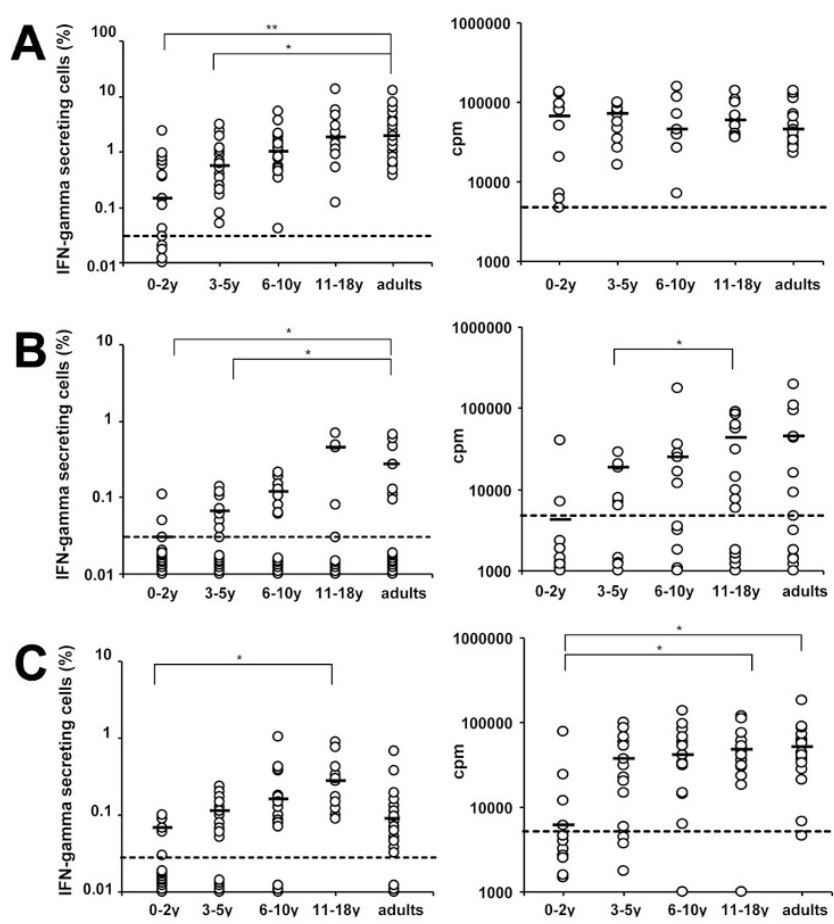

Figure 2. IFN $\gamma$ - and proliferative responses to $\mathrm{CD} 3, \mathrm{CMV}$, and $\mathrm{AdV}$ in immunocompetent children according to their age. Results on IFN $\gamma$ - and proliferative responses are expressed as individual percentages of $\mathrm{CD}^{+} \mathrm{T}$ cells secreting IFN $\gamma$ among total $\mathrm{CD}^{+}{ }^{+} \mathrm{T}$ cells $(l e f t)$ or $\mathrm{cpm}($ right), respectively, after in vitro stimulation with a $\mathrm{CD} 3 \mathrm{MAb}(A), \mathrm{CMV}(B)$, or AdV lysates $(C)$. The dashed bars indicate the cutoff between positive and negative responses (i.e. $0.03 \%$ for IFN $\gamma$ responses and $5000 \mathrm{cpm}$ with a SI $>5$ for proliferative responses). Median values of all responses (CD3) or in responders (CMV or AdV) are indicated by horizontal line. The $p$ values only when significant are reported $(* p \leq 0.05 ; * * \leq 0.005)$.

CD4 T-cells responses to CMV were not confronted to CMV serological status in infants (age, $0-1$ y) because of interference with maternal antibodies. None evidenced cellular immune responses.

In the 1-2 y group, five children presented with a $\mathrm{CMV}^{+}$ serostatus. Three of five evidenced IFN $\gamma$ responses $>0.03 \%$ and two of four evaluable for proliferative responses evidenced cpm over the threshold of positivity (i.e. $5000 \mathrm{cpm}$ ). Later, there was a clear increase in the intensity levels of IFN $\gamma$ responses and a trend toward an increase in the intensity levels of proliferative responses to the CMV Ag with aging. In children older than 2 y and as noted above all but one (20/21) with a $\mathrm{CMV}^{+}$serostatus evidenced IFN $\gamma$ responses $(95 \%)$ and all evidenced proliferative responses.

With regard to $\mathrm{AdV}$, a great majority of children are supposed to be protected against the virus, because of maternal Ig transmission in infants, followed by early natural immunization from 1 to $2 \mathrm{y}$ of age (14). In agreement, in the $0-2$ y group, the mean percentage of CD4-secreting IFN $\gamma$ following stimulation with AdV $(0.10 \%)$ was not significantly different from background (unstimulated cultures; $0.05 \%)$. However, the mean percentages in $\mathrm{AdV}$-stimulated cultures were clearly more elevated than background in all other groups $(0.15$ versus $0.05 \%$; 0.25 versus $0.06 \%$, and
0.39 versus $0.10 \%$ in the $3-5,6-10$, and $11-18$ y groups, respectively).

As shown in Figure 2, cellular criteria of natural immunization as evidenced by AdV-specific IFN $\gamma$ responses $>0.03 \%$ was observed in only 5 of $15(33 \%)$ children in the $0-2$ y group but 11 of $16(69 \%)$ in the $3-5$ y group, 12 of $15(80 \%)$ in the 6-10 y group, and all $11(100 \%)$ in the $11-18$ y group. Mean (not shown) or median (Fig. 2) percentages of IFN $\gamma$ secreting $\mathrm{CD}^{+}{ }^{+} \mathrm{T}$ cells in responders (defined by responses $>0.03 \%$ ) were lower in the $0-2 \mathrm{y}$ group. In contrast with CMV-specific IFN $\gamma$ responses, values in children were similar and even higher than in adults. Finally, lower proliferative responses to AdV were observed in the 0-2 y group. However, optimal levels were observed yet in the 3-5 y group.

Variations in the distribution of immune cells secreting IL2 alone, IFN $\gamma$ alone, or both cytokines. Among the studied population, 19 children and 17 healthy adults who responded to AdV or CMV were analyzed simultaneously for IL2 and IFN $\gamma$ responses. As illustrated in Figure 3 for one representative healthy child, virus-specific CD4 are distributed into three categories as follows: CD4-secreting IFN $\gamma$ alone, IL2 alone, or IL2 + IFN $\gamma$. As shown in Figure 4, in both children older than 3 y and adults, CD4-secreting IFN $\gamma$ alone predominated over CD4-secreting IL2 + IFN $\gamma$ in CMV-stimulated cultures (median: 0.06 and 0.09 versus 0.04 and 0.03 ), but CD4-secreting IL2 + IFN $\gamma$ predominated over CD4-secreting IFN $\gamma$ alone in AdV-stimulated cultures ( 0.09 and 0.05 versus 0.06 and 0.02 ). Finally, IL2 responses predominated over IFN $\gamma+$ IL2 responses after stimulation by the CD3 MAb in the 3-5 y group and also in adults. These differences in the profiles of cytokine responses to AdV and CMV are highly significant (Table 1).

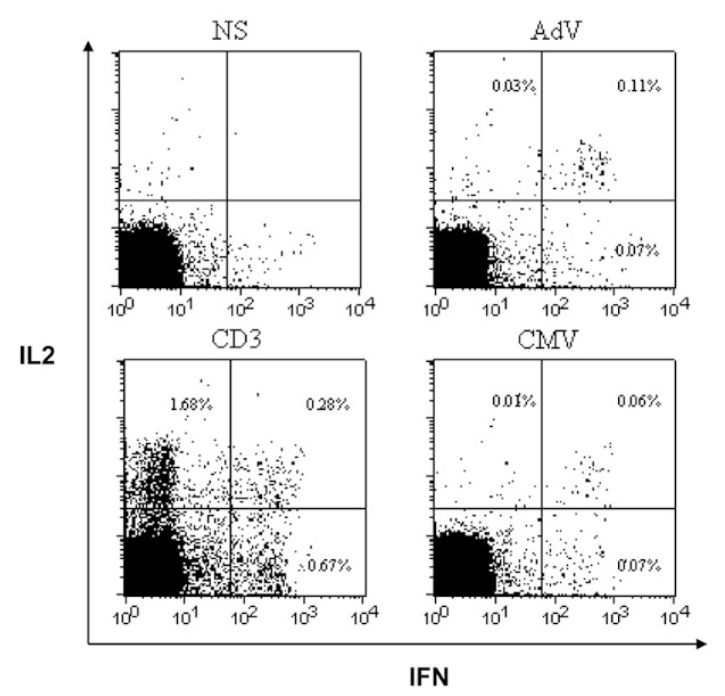

Figure 3. Representative cytokine responses to CD3, CMV, or AdV in one child. Data from one representative healthy child are shown as dot plot obtained after lymphocyte gating and subsequent $\mathrm{CD} 3{ }^{+} \mathrm{CD}^{+}$cell gating of unstimulated culture (NS), culture stimulated with an anti-CD3 MAb (CD3), or with viral antigenic preparations (CMV or AdV). The percentages of cells secreting IL2 alone, IL2 + IFN $\gamma$, or IFN $\gamma$ alone are indicated in the upper left, upper right, and lower right quadrants, respectively, after deduction of background found in unstimulated culture. 

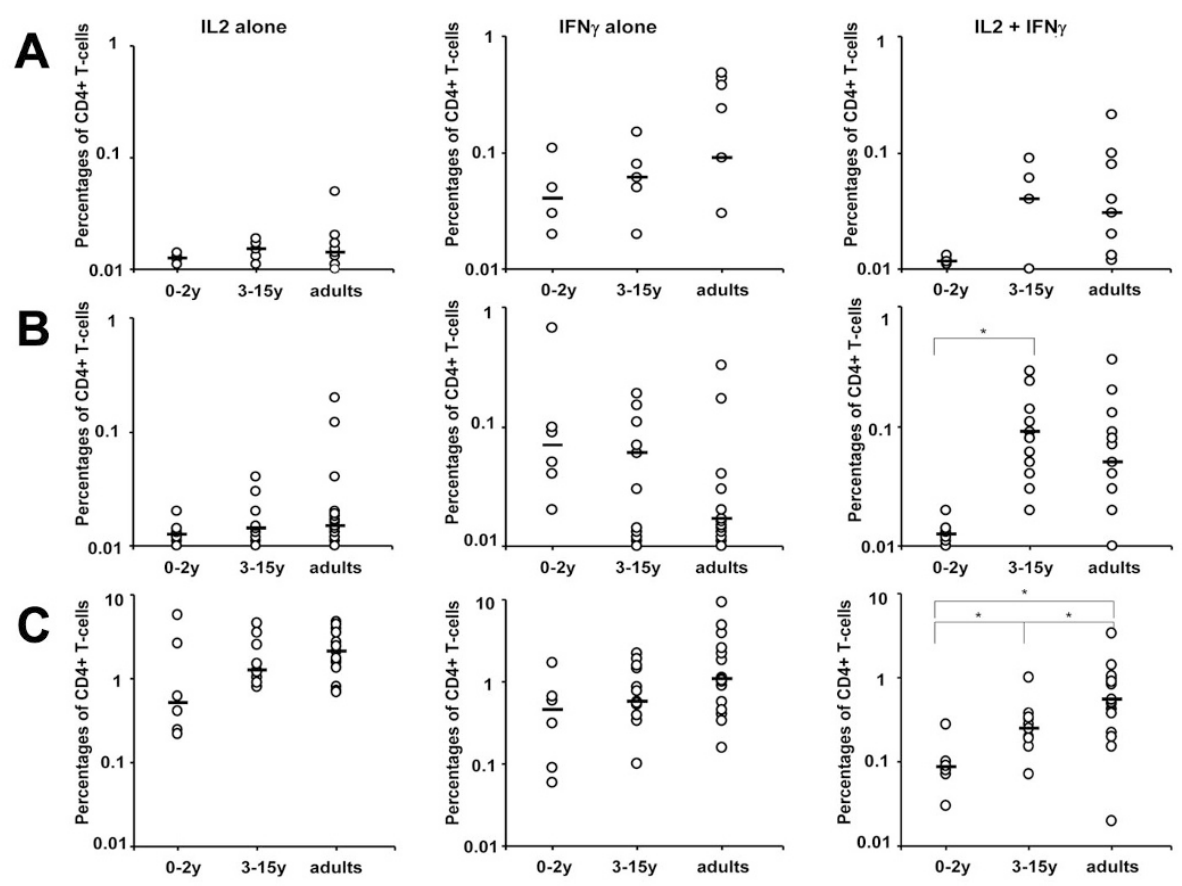

Figure 4. Distribution of memory T cells secreting IL2 alone, IFN $\gamma$ alone, or IL2 + IFN $\gamma$. Nine children (mean age, $5.7 \mathrm{y}$; range, 1.5-15 y) and nine adults with a CMV positive serostatus were evaluated for responses to CMV (A). Nineteen children (mean age, $5.4 \mathrm{y}$; range, 1-15 y) and 17 healthy adults with IFN $\gamma$ responses to AdV were evaluated for IL2 and IFN $\gamma$ responses to AdV (B). All were also evaluated for responses to the CD3 MAb (C). Results are expressed as individual percentages of $\mathrm{CD}^{+} \mathrm{T}$ cells secreting IL2 alone, IFN $\gamma$ alone, or both cytokines after stimulation. Median values are indicated by horizontal line. Only $p$ values when significant are reported $(* p \leq 0.05 ; * * p \leq 0.005)$.

Table 1. Distinct profiles of cytokine responses to $A d V$ and to $C M V$

\begin{tabular}{lccc}
\hline & \multicolumn{2}{c}{$\left[\begin{array}{c}\text { IL2 }+ \text { IFN } \gamma] \%-[\mathrm{IFN} \gamma \\
\text { alone }] \% \text { responses to* }\end{array}\right.$} & \\
\cline { 2 - 3 } & $\mathrm{CMV}$ & $\mathrm{AdV}$ & $p \dagger$ \\
\hline $\begin{array}{l}\text { Children aged 3-15 y, } \\
\text { median }\end{array}$ & $-0.02(n=6)$ & $+0.04(n=13)$ & 0.01 \\
Adults, median & $-0.07(n=10)$ & $+0.03(n=18)$ & 0.0001 \\
\hline
\end{tabular}

* To determine which functional subset predominates, the percentage of CD4-secreting IFN $\gamma$ alone was deduced from the percentage of CD4secreting IL2 + IFN $\gamma$ in each group.

$\dagger p$ values compared the results of responses with AdV and CMV in either children aged $3-15$ y or adults.

In $0-2$ y group, the decreased IFN $\gamma$-response to CMV (Fig. 2) was associated with a trend toward lower IL2 + IFN $\gamma$ secretion ( $p=0.1$; Fig. 4). The percentages of AdV-specific CD4 that secreted IL2 $+\operatorname{IFN} \gamma$ were also less $(p<0.02)$, whereas the percentages of AdV-specific CD4-secreting IFN $\gamma$ alone were not decreased and even increased in the youngest group. Moreover, the percentages of CD4 that secrete IL2 + IFN $\gamma$ in responses to the CD3 MAb were lower $(p<0.05)$ in the $0-2$ compared with the $3-15$ y group, which in turn were lower $(p<0.05)$ than in adults.

\section{DISCUSSION}

The characteristics of memory $\mathrm{CD} 4^{+} \mathrm{T}$ cells that developed after resolution of infections in immunocompetent children must be known to verify the protective activity of potential vaccine candidates. They are also required for a better prediction of infectious risk in children with malignancies, children with congenital immunodeficiencies, or children receiving intensive immunosuppression.

Saule et al. (25) first reported a linear increase of TCM and $\mathrm{TEM} \mathrm{CD}^{+} \mathrm{T}$ cells with aging. Our results showing predom- inant accumulation of TCM over TEM CD4 at any age are at variance with this previous study. In addition, to be exploited in clinical practice, these results highlight that maintenance of proportions between CD4 TEM and TCM subsets may be critical for the immune system and are under strict homeostatic control.

By using a CD3 MAb that activates memory $\mathrm{T}$ cells as a polyclonal activator, we show that IFN $\gamma$ responses increase with time. This observation is in agreement with previous studies that used other polyclonal activators $(5,6,26)$. Low responses in early age could reflect the limited capacity to respond to single Ags as suggested by others. Continuous increase could also result from exposure to continuously growing numbers of pathogens encountered. In an effort to distinguish between these two possibilities, we analyzed further IFN $\gamma$ responses on a per CD45RA ${ }^{-}$CD4 basis. However, high interindividual variabilities among the limited series of children precluded to draw a conclusion.

In contrast with IFN $\gamma$ responses, proliferative responses to CD3 seemed poor and even not depressed in the $0-2$ y group, suggesting higher proliferative capacity related to IFN $\gamma$ secretion at that age. An alternative trivial explanation could be competition between cells for limiting factors in $3 \mathrm{~d}$ proliferation assays.

Analysis of responses to specific Ags is expected to be more discriminatory. Decreased IFN $\gamma$ responses to CMV in the first year of life are well known $(8,9,27-29)$. However, only two recent studies assessed production of multiple cytokines in young age $(27,28)$. The two studies compared cytokine production in children from 1- to 4-y-old with congenital infection versus their respective mothers with CMV infection of similar duration. The proportion of CMV-specific CD4secreting IL2 alone, IFN $\gamma$ alone, or IL2 + IFN $\gamma$ were lower in children. Lower total IFN $\gamma$ responses and also a trend toward 
lower IFN $\gamma$ alone, IL2 alone, and IFN $\gamma+$ IL2 responses were noted in the $0-2$ y group from our series. Our results further suggest that CD4 secreting both IL $2+$ IFN $\gamma$ cytokines are relatively more depressed than $\mathrm{CD} 4$-secreting IFN $\gamma$ alone.

Age-related expansion of anti-CMV CD4 has been reported in long-term adult carriers $(29,30)$. We extended this observation to childhood. In addition, our results support that TEM CD4 (secreting IFN $\gamma$ alone) predominate over TCM CD4 (secreting IL2 + IFN $\gamma$ ), which predominate over CMVspecific CD4-secreting IL2 alone at any age.

CMV infection induces expansion of differentiated $\mathrm{CD} 8^{+} \mathrm{T}$ cells $(31,32)$. Its effect on the CD4 T-cell pool is less well known. Here, the proportion of naïve/memory CD4 T-cell pools was not different in the $\mathrm{CMV}^{+}$and $\mathrm{CMV}^{-}$groups of children (not shown). IFN $\gamma$ responses to $\mathrm{AdV}$ were identical in the two groups $(0.17 \%$ both). However, a trend toward higher IFN $\gamma$ responses to polyclonal activation by the CD3 $\mathrm{MAb}$ was observed in the $\mathrm{CMV}^{+}$group compared with the $\mathrm{CMV}^{-}$group (2.29 versus $\left.0.81 \%\right)$. These results are reminiscent with Miles et al. (9) study, showing a trend toward increased IFN $\gamma$ responses to a nominal Ag (measle) but a clear increased response to a polyclonal activator (SEB) in $\mathrm{CMV}^{+}$ children.

The intensity levels of total IFN $\gamma$ responses (IFN $\gamma$ alone + IL2/IFN $\gamma$ ) to AdV were lower in the 0-2 y group (Fig. 2). As serious complications of $\mathrm{AdV}$-associated disease were not noticed in this series of young bone-marrow donors, sufficient levels of immune surveillance were likely reached to contain AdV. Kalu et al. (33) recently suggested that AdV could persist in upper respiratory infections at least in children. However, whether low cellular responses to AdV could be involved in prolonged virus persistence in early age remains to be documented.

The continuous increase in IFN $\gamma$ responses to CMV contrasts with responses to AdV that reach plateau levels from 3 y of age. This difference was likely related to acute infection with AdV but persistent infection with CMV in which recurrent reactivations occur. $\mathrm{Ag}$ persistence (CMV) versus clearance (AdV) could also account for the predominance of IFN $\gamma$ secretion in CMV infection but of CD4-secreting IL2 + IFN $\gamma$ secretion in AdV infection. Indeed, a polyfunctional pattern is primarily observed in virus infections with controlled viral replication, whereas a predominant IFN $\gamma$ response is mostly observed in ongoing replication in various infections such as CMV (34), HIV (35), hepatitis C virus (36), and Mycobacterium tuberculosis (37).

Finally, CD4-secreting IL2 alone predominated after stimulation with the CD3 MAb. A predominant IL2-response was previously found in the model of vaccination by the tetanus toxoid protein (34) associated with Ag clearance. The predominance of CD4-secreting IL2 alone in response to the CD3 MAb could therefore reflect clearance of most Ags present in the nature.

In conclusion, polyfunctional responses are defective in children aged 0-2 y. In contrast, the levels of CD4-secreting IFN $\gamma$ alone were relatively less decreased. This observation supports that both qualitative and quantitative differences contribute to the relatively poor ability of young children to fight infection. In addition, the development of immune memory functions differs in CMV (persistent) and AdV (acute) infections. Moreover, the development of immune responses to the anti-CD3 monoclonal has its own specificity. These observations invite to revisit CD4 responses to other pathogens in children based on their capacity to secrete multiple cytokines.

Acknowledgments. We thank Elodie Geneletti, Guylaine Boiry, Pricilia Egremonte, Judith Tholle, and Anne-Marie Courchinoux for excellent technical assistance and Celine Neto for typing the article and making the figures.

\section{REFERENCES}

1. Harari A, Dutoit V, Cellerai C, Bart PA, Du Pasquier RA, Pantaleo G 2006 Functional signatures of protective antiviral T-cell immunity in human virus infections. Immunol Rev 211:236-254

2. Luzuriaga K, Holmes D, Hereema A, Wong J, Panicali DL, Sullivan JL 1995 HIV-1-specific cytotoxic T lymphocyte responses in the first year of life. J Immunol $154: 433-443$

3. Smith FS, Portner A, Leggiadro RJ, Turner EV, Hurwitz JL 1994 Age-related development of human memory T-helper and B-cell responses toward parainfluenza virus type-1. Virology 205:453-461

4. Gasparoni A, Ciardelli L, Avanzini A, Castellazzi AM, Carini R, Rondini G, Chirico G 2003 Age-related changes in intracellular TH1/TH2 cytokine production, immunoproliferative $\mathrm{T}$ lymphocyte response and natural killer cell activity in newborns, children and adults. Biol Neonate 84:297-303

5. Chipeta J, Komada Y, Zhang XL, Deguchi T, Sugiyama K, Azuma E, Sakurai M 1998 CD4 + and CD8 + cell cytokine profiles in neonates, older children, and adults: increasing $\mathrm{T}$ helper type 1 and $\mathrm{T}$ cytotoxic type 1 cell populations with age. Cell Immunol 183:149-156

6. Hoffmann F, Albert MH, Arenz S, Bidlingmaier C, Berkowicz N, Sedlaczek S, Till H, Pawlita I, Renner ED, Weiss M, Belohradsky BH 2005 Intracellular T-cell cytokine levels are age-dependent in healthy children and adults. Eur Cytokine Netw 16:283-288

7. Verhoeven D, Teijaro JR, Farber DL 2008 Heterogeneous memory T cells in antiviral immunity and immunopathology. Viral Immunol 21:99-113

8. Hayashi N, Kimura H, Morishima T, Tanaka N, Tsurumi T, Kuzushima K 2003 Flow cytometric analysis of cytomegalovirus-specific cell-mediated immunity in the congenital infection. J Med Virol 71:251-258

9. Miles DJ, Sande M, Kaye S, Crozier S, Ojuola O, Palmero MS, Sanneh M, Touray ES, Waight P, Rowland-Jones S, Whittle H, Marchant A 2008 CD4(+) T cell responses to cytomegalovirus in early life: a prospective birth cohort study. J Infect Dis 197:658-662

10. Mäkelä M, Marttila J, Simell O, Ilonen J 2004 Rotavirus-specific T-cell responses in young prospectively followed-up children. Clin Exp Immunol 137:173-178

11. Brandenburg AH, Kleinjan A, van Het Land B, Moll HA, Timmerman HH, de Swart RL, Neijens HJ, Fokkens W, Osterhaus AD 2000 Type 1-like immune response is found in children with respiratory syncytial virus infection regardless of clinical severity. J Med Virol 62:267-277

12. Arvin AM 2008 Humoral and cellular immunity to varicella-zoster virus: an overview. J Infect Dis 197:S58-S60

13. Zeman AM, Holmes TH, Stamatis S, Tu W, He XS, Bouvier N, Kemble G, Greenberg HB, Lewis DB, Arvin AM, Dekker CL 2007 Humoral and cellular immune responses in children given annual immunization with trivalent inactivated influenza vaccine. Pediatr Infect Dis J 26:107-115

14. Mast TC, Kierstead L, Gupta SB, Nikas AA, Kallas EG, Novitsky V, Mbewe B, Pitisuttithum P, Schechter M, Vardas E, Wolfe ND, Aste-Amezaga M, Casimiro DR, Coplan P, Straus WL, Shiver JW 2010 International epidemiology of human pre-existing AdV type-5, type-6, type-26 and type-36 neutralizing antibodies: correlates of high Ad5 titers and implications for potential HIV vaccine trials. Vaccine 28:950-957

15. Thorner AR, Lemckert AA, Goudsmit J, Lynch DM, Ewald BA, Denholtz M, Havenga MJ, Barouch DH 2006 Immunogenicity of heterologous recombinant AdV prime-boost vaccine regimens is enhanced by circumventing vector cross-reactivity. J Virol 80:12009-12016

16. Adler SP 1992 Cytomegalovirus transmission and child day care. Adv Pediatr Infect Dis $7: 109-122$

17. Feuchtinger T, Lucke J, Hamprecht K, Richard C, Handgretinger R, Schumm M, Greil J, Bock T, Niethammer D, Lang P 2005 Detection of adenovirus-specific T cells in children with adenovirus infection after allogeneic stem cell transplantation. Br J Haematol 128:503-509

18. Schoenberger SP, Toes RE, van der Voort EI, Offringa R, Melief CJ 1998 T-cell help for cytotoxic $\mathrm{T}$ lymphocytes is mediated by CD40-CD40L interactions. Nature 393:480-483

19. Sun JC, Bevan MJ 2003 Defective CD8 T cell memory following acute infection without CD4 T cell help. Science 300:339-342

20. Klenerman P, Hill A $2005 \mathrm{~T}$ cells and viral persistence: lessons from diverse infections. Nat Immunol 6:873-879 
21. Hu J, Vaquero C, Huet S, Bernard A, Sterkers G 1987 Interleukin 2 up-regulates its own production. J Immunol 139:4109-4115

22. Krishnaraj R, Bhooma T 1996 Cytokine sensitivity of human NK cells during immunosenescence. 2. IL2-induced interferon gamma secretion. Immunol Lett 50:59-63

23. Veltrop-Duits LA, Heemskerk B, Sombroek CC, van Vreeswijk T, Gubbels S, Toes RE, Melief CJ, Franken KL, Havenga M, van Tol MJ, Schilham MW 2006 Human CD4+ T cells stimulated by conserved adenovirus 5 hexon peptides recognize cells infected with different species of human adenovirus. Eur J Immunol 36:2410-2423

24. Guérin V, Dalle JH, Pedron B, Ouachee-Chardin M, Yakouben K, Baruchel A, Sterkers G 2010 Cellular immune parameters associated with spontaneous control of CMV in children who underwent transplantation. Bone Marrow Transplant 45:442449

25. Saule P, Trauet J, Dutriez V, Lekeux V, Dessaint JP, Labalette M 2006 Accumulation of memory $\mathrm{T}$ cells from childhood to old age: central and effector memory cells in CD4(+) versus effector memory and terminally differentiated memory cells in CD8(+) compartment. Mech Ageing Dev 127:274-281

26. Härtel C, Adam N, Strunk T, Temming P, Muller-Steinhardt M, Schultz C 2005 Cytokine responses correlate differentially with age in infancy and early childhood. Clin Exp Immunol 142:446-453

27. Tu W, Chen S, Sharp M, Dekker C, Manganello AM, Tongson EC, Maecker HT, Holmes TH, Wang Z, Kemble G, Adler S, Arvin A, Lewis DB 2004 Persistent and selective deficiency of CD4 $+\mathrm{T}$ cell immunity to cytomegalovirus in immunocompetent young children. J Immunol 172:3260-3267

28. Kaye S, Miles D, Antoine P, Burny W, Ojuola B, Kaye P, Rowland-Jones S, Whittle H, van der Sande M, Marchant A 2008 Virological and immunological correlates of mother-to-child transmission of cytomegalovirus in The Gambia. J Infect Dis 197:1307-1314

29. Pourgheysari B, Khan N, Best D, Bruton R, Nayak L, Moss PA 2007 The cytomegalovirus-specific CD4+ T-cell response expands with age and markedly alters the CD4+ T-cell repertoire. J Virol 81:7759-7765
30. Vescovini R, Biasini C, Fagnoni FF, Telera AR, Zanlari L, Pedrazzoni M, Bucci L, Monti D, Medici MC, Chezzi C, Franceschi C, Sansoni P 2007 Massive load of functional effector CD4 + and CD8 $+\mathrm{T}$ cells against cytomegalovirus in very old subjects. J Immunol 179:4283-4291

31. Gratama JW, Naipal AM, Oosterveer MA, Stijnen T, Kluin-Nelemans HC, Ginsel LA, den Ottolander GJ, Hekker AC, D'Amaro J, van der Giessen M, Tanke HJ 1987 Effects of herpes virus carrier status on peripheral T lymphocyte subsets. Blood 70:516-523

32. Weinberger B, Lazuardi L, Weiskirchner I, Keller M, Neuner C, Fischer KH, Neuman B, Wurzner R, Grubeck-Loebenstein B 2007 Healthy aging and latent infection with CMV lead to distinct changes in CD8+ and CD4+ T-cell subsets in the elderly. Hum Immunol 68:86-90

33. Kalu SU, Loeffelholz M, Beck E, Patel JA, Revai K, Fan J, Henrickson KJ, Chonmaitree T 2010 Persistence of adenovirus nucleic acids in nasopharyngeal secretions: a diagnostic conundrum. Pediatr Infect Dis J 29:746-750

34. Harari A, Vallelian F, Meylan PR, Pantaleo G 2005 Functional heterogeneity of memory CD4 $\mathrm{T}$ cell responses in different conditions of antigen exposure and persistence. J Immunol 174:1037-1045

35. Younes SA, Yassine-Diab B, Dumont AR, Boulassel MR, Grossman Z, Routy JP, Sekaly RP 2003 HIV-1 viremia prevents the establishment of interleukin 2-producing HIV-specific memory CD4+ T cells endowed with proliferative capacity. J Exp Med 198:1909-1922

36. Ciuffreda D, Comte D, Cavassini M, Giostra E, Buhler L, Perruchoud M, Heim MH, Battegay M, Genne D, Mulhaupt B, Malinverni R, Oneta C, Bernasconi E, Monnat M, Cerny A, Chuard C, Borovicka J, Mentha G, Pascual M, Gonvers JJ, Pantaleo G, Dutoit V 2008 Polyfunctional HCV-specific T-cell responses are associated with effective control of HCV replication. Eur J Immunol 38:2665-2677

37. Millington KA, Innes JA, Hackforth S, Hinks TS, Deeks JJ, Dosanjh DP, GuyotRevol V, Gunatheesan R, Klenerman P, Lalvani A 2007 Dynamic relationship between IFN-gamma and IL-2 profile of Mycobacterium tuberculosis-specific T cells and antigen load. J Immunol 178:5217-5226 